\title{
Effects of saline stress on Eucalyptus seedlings
}

\author{
R.A. Fathi and D. Prat \\ Laboratoire de Génétique des Populations d'Arbres Forestiers, Laboratoire associé CTFT- \\ ENGREF, ENGREF, 14, rue Girardet, F-54042 Nancy, France
}

\section{Introduction}

Forests in arid countries, especially around the Sahel, are overexploited because of the great needs of local populations for wood. Native species adapted to aridity do not produce enough wood. Plantations of adapted and fast-growing species seem to be the best way to meet local demand. Difficulties arise not only from drought but also from the salinity of soils (Chapman, 1975). Plants must be selected for drought- and salt-tolerance and then grown in a favorable environment. Some woody species, such as Eucalyptus, are fast-growing and very plastic (Martin, 1987). Eucalyptus plantations may be one of the ways to produce wood under these difficult conditions and thus spare the natural stands. Three Eucalyptus species (E. alba, E. camaldulensis and $E$. microtheca) were tested for their salt-tolerance. Saline stress was applied at germination and to seedlings in a greenhouse.

\section{Materials and Methods}

Seeds were collected in the natural range of the 3 species; they were available as species- representative seedlots or provenance-representative seedlots.

Seeds were sown on perlite soaked with nutritive medium (Murashige and Skoog, 1962) in jars, with salt $(\mathrm{NaCl}, 50-200 \mathrm{mM})$ added to study salt-tolerance at the germination stage. For measurement of salt-tolerance of seedlings in the greenhousie, seeds were sown on vermiculite, plants were replanted in seed-pans filled with vermiculite and watered with a dilute nutritive solution ( $N, P, K$ and oligonutrients). 3 mo old seedlings were watered for $1 \mathrm{mo}$ with and a saline solution $(\mathrm{NaCl}, 100-600 \mathrm{mM})$ added to the nutritive solution (Fathi, 1987).

Mineral elements $(\mathrm{Ca}, \mathrm{K}$ and $\mathrm{Na})$ in the plants were estimated by flame photometry. Chloride was titrated according to Fries and Getrost (1977; reagent: chloranilic acid, mercury salt) by photometry. Organic components were also analyzed by photometry: soluble sugars (reagent: anthrone; Savouré, 1980), soluble proteins, amino acids and proline (Troll and Lindsley, 1955). Analyses were generally carried out at the end of the stress application.

\section{Effects of saline stress on germination}

The application of saline stress led to a reduced germination rate. $E$. alba was the most sensitive species; only one provenance was able to germinate under a 200 $\mathrm{mM}$ saline stress. E. camaldulensis was more affected by saline stress in the sur- 
Table I. Effects of saline stress on E. microtheca seedlings in the greenhouse.

\begin{tabular}{|c|c|c|c|c|c|c|}
\hline \multirow[t]{2}{*}{ Characteristic } & \multirow{2}{*}{$\begin{array}{l}\text { Saline } \\
\text { stress }\end{array}$} & \multicolumn{5}{|c|}{ Provenance } \\
\hline & & M6 & $M 7$ & $M 8$ & M9 & $M 11$ \\
\hline $\begin{array}{l}\text { Growth (ht incre- } \\
\text { ment, last } 2 \text { wk of } \\
\text { stress, cm) }\end{array}$ & $\begin{array}{l}\text { control } \\
300 \mathrm{mM} \\
600 \mathrm{mM}\end{array}$ & $\begin{array}{r}10.1 \\
3.5 \\
0.2\end{array}$ & $\begin{array}{r}15.2 \\
3.9 \\
0.1\end{array}$ & $\begin{array}{r}15.6 \\
5.1 \\
0.1\end{array}$ & $\begin{array}{r}13.7 \\
8.3 \\
0.2\end{array}$ & $\begin{array}{r}15.7 \\
6.0 \\
0.2\end{array}$ \\
\hline $\begin{array}{l}\mathrm{K} \text { content in roots } \\
(\mu \mathrm{mol} / \mathrm{g} \text { fr. wt })\end{array}$ & $\begin{array}{l}\text { control } \\
300 \mathrm{mM} \\
600 \mathrm{mM}\end{array}$ & $\begin{array}{r}156 \\
59 \\
113\end{array}$ & $\begin{array}{r}132 \\
72 \\
97\end{array}$ & $\begin{array}{r}142 \\
71 \\
79\end{array}$ & $\begin{array}{r}133 \\
93 \\
83\end{array}$ & $\begin{array}{r}135 \\
67 \\
113\end{array}$ \\
\hline $\begin{array}{l}\mathrm{Cl} \text { content in leaves } \\
(\mu \mathrm{mol} / \mathrm{g} \mathrm{fr} . \mathrm{wt})\end{array}$ & $\begin{array}{l}\text { control } \\
300 \mathrm{mM} \\
600 \mathrm{mM}\end{array}$ & $\begin{array}{r}54 \\
422 \\
491\end{array}$ & $\begin{array}{r}58 \\
288 \\
392\end{array}$ & $\begin{array}{r}89 \\
438 \\
418\end{array}$ & $\begin{array}{r}94 \\
584 \\
676\end{array}$ & $\begin{array}{r}85 \\
533 \\
569\end{array}$ \\
\hline $\begin{array}{l}\text { Na content in leaves } \\
(\mu \mathrm{mol} / \mathrm{g} \text { fr. } w t)\end{array}$ & $\begin{array}{l}\text { control } \\
300 \mathrm{mM} \\
600 \mathrm{mM}\end{array}$ & $\begin{array}{r}12 \\
345 \\
375\end{array}$ & $\begin{array}{r}22 \\
235 \\
300\end{array}$ & $\begin{array}{r}19 \\
247 \\
417\end{array}$ & $\begin{array}{r}7 \\
265 \\
311\end{array}$ & $\begin{array}{r}5 \\
329 \\
361\end{array}$ \\
\hline $\begin{array}{l}\text { Na content in roots } \\
(\mu \mathrm{mol} / \mathrm{g} \text { fr. } w \mathrm{t}) \\
\text { dead plants }\end{array}$ & $\begin{array}{l}\text { control } \\
300 \mathrm{mM} \\
600 \mathrm{mM} \\
600 \mathrm{mM}\end{array}$ & $\begin{array}{r}75 \\
1342 \\
2708 \\
5123\end{array}$ & $\begin{array}{r}125 \\
1720 \\
3022 \\
4879\end{array}$ & $\begin{array}{l}126 \\
1422 \\
3188 \\
4081\end{array}$ & $\begin{array}{r}162 \\
1845 \\
2811 \\
4646\end{array}$ & $\begin{array}{r}53 \\
1320 \\
3646 \\
3853\end{array}$ \\
\hline $\begin{array}{l}\text { Soluble sugar content } \\
\text { (mg/g fr. wt) }\end{array}$ & $\begin{array}{l}\text { control } \\
300 \mathrm{mM} \\
600 \mathrm{mM}\end{array}$ & $\begin{array}{l}27.6 \\
29.0 \\
30.7\end{array}$ & $\begin{array}{l}22.8 \\
28.0 \\
37.8\end{array}$ & $\begin{array}{l}25.0 \\
31.4 \\
32.9\end{array}$ & $\begin{array}{l}24.1 \\
26.7 \\
36.5\end{array}$ & $\begin{array}{l}24.8 \\
26.2 \\
34.4\end{array}$ \\
\hline $\begin{array}{l}\text { Proline content } \\
(\mu \mathrm{mol} / \mathrm{g} \text { fr. } \mathrm{wt})\end{array}$ & $\begin{array}{l}\text { control } \\
300 \mathrm{mM} \\
600 \mathrm{mM}\end{array}$ & $\begin{array}{l}0.9 \\
1.6 \\
2.5\end{array}$ & $\begin{array}{l}0.8 \\
3.7 \\
3.0\end{array}$ & $\begin{array}{l}1.1 \\
6.8 \\
1.0\end{array}$ & $\begin{array}{l}1.2 \\
4.8 \\
0.1\end{array}$ & $\begin{array}{l}1.7 \\
4.9 \\
3.0\end{array}$ \\
\hline \multicolumn{2}{|c|}{$\begin{array}{l}\text { Stress reducing germination rate } \\
\text { to } 50 \% \text { of control }(\mathrm{mM} \mathrm{NaCl})\end{array}$} & $>200$ & $>200$ & 200 & $>200$ & $>200$ \\
\hline \multicolumn{2}{|c|}{$\begin{array}{l}\text { Stress reducing ht increment } \\
\text { of seedlings in greenhouse } \\
\text { to } 50 \% \text { of the control (mM NaCl) }\end{array}$} & 220 & 180 & 200 & 350 & 200 \\
\hline
\end{tabular}

Comparison of several provenances of $E$. microtheca under saline stress (the saline stress effect was highly significant (at the 0.01 or more generally 0.001 level) for all characteristics; the provenance effect was highly significant only on the growth; and the saline stress $x$ provenance interaction was highly significant only on the growth and the proline content).

vival tolerance (45 $\mathrm{d}$ after sowing) than in the germination rates, but it was the opposite for $E$. microtheca. Some provenances were not sensitive to saline stress up to $200 \mathrm{mM}$. Seedlings exposed to saline stress accumulated large amounts of sodium, especially $E$. alba, where calcium contents were also higher (Fathi and
Prat, 1988). E. microtheca seemed to be the most tolerant species and was therefore studied in the greenhouse.

The growth of plants was significantly reduced by saline stress (Table I). The accumulation of sodium was more limited in the leaves for the strongest saline stress, but not in stems or roots. In roots, 
the average sodium content became higher than in the saline stress solution. The concentration of chloride in leaves was higher than that of sodium. The potassium content was significantly lower in roots of plants exposed to a $300 \mathrm{mM}$ saline stress.

The sodium concentration increased from the 1st wk of stress application and was higher in the stem than in leaves. During the saline stress application, the potassium content in leaves and stems decreased gradually. After the stress application, plants were watered normally: the sodium content in leaves increased immediately, probably due to a release of the sodium accumulated in the roots.

Increased sugar, protein, amino acid and proline contents were induced by saline stress application. Proline might represent a large part (up to $25 \%$ ) of free amino acids, but its content in leaves was quite variable depending upon the provenance.

\section{Conclusion}

Saline stress reduced growth of plants and induced changes in mineral and organic component contents. The sensitivity varied according to the species or the provenance. The most sensitive provenances of $E$. microtheca showed the largest amount of sodium in leaves or stems; the sodium content of living plants was very close to that of plants killed by the saline stress. Plants of these provenances (M8 and $\mathrm{M} 11$ ) appeared to be unable to accumulate more sodium.

Our study did not identify a predictive characteristic for salt-tolerance without saline stress application. However, the most tolerant provenance (M9) was from the most arid stand in Australia. Ecological studies might be useful for prediction of salt-tolerance.

\section{References}

Chapman J. (1975) The salinity problem in general, its importance, and distribution with special reference to natural halophytes. In: Plants in Saline Environment, (Poljakoff-Mayber A. et al., eds.), Springer-Verlag, Berlin, pp. 7-24

Fathi R.A. (1987) Etude et sélection de jeunes plants d'Eucalyptus tolérants au sel, dans des populations de divers niveaux de variabilité. Thesis, Université Nancy I, France

Fathi R.A. \& Prat D. (1988) Variabilité du comportement de jeunes plants d'Eucalyptus soumis à un stress salin. In: Groupe d'étude de l'arbre, Paris in press

Fries J. \& Getrost H. (1977) Organic Reagents for Trace Analysis. Merck, Darmstadt

Martin B. (1987) Amélioration génétique des Eucalyptus tropicaux. Contribution majeure à la foresterie clonale. Thesis, Université Paris XIOrsay, France

Murashige T. \& Skoog F. (1962) A revised medium for rapid growth and bioassays with tobacco tissue culture. Physiol. Plant. 15, 473497

Savouré B. (1980) In: Manipulations pratiques en physiologie végétale. Masson, Paris

Troll W. \& Lindsley J. (1955) A photometric method for the determination of proline. J. Biol. Biochem. 215, 655-660 